\title{
Ontogenic development of the mouth and digestive tract in larval Malaysian mahseer, Tor tambroides Bleeker
}

\begin{abstract}
This study analysed morphology and histology of the developing mouth and digestive tract of the Malaysian mahseer larvae to assess the best weaning time to a compound diet for the fry on the basis of their morphological features. The mouth development was monitored using light and scanning electron microscopy; the development of the alimentary canal was followed histologically using light microscopy after haematoxylin-eosin staining. The larval mouth opened 1 day after hatching $(1 \mathrm{DAH})$; the histological structures of oesophagus were completed by $5 \mathrm{DAH}$. At $2 \mathrm{DAH}$, differentiation of enterocytes began, and at $7 \mathrm{DAH}$ the supranuclear protein inclusion appeared in the posterior intestine. The hepatopancreas was structurally completed at 4-5 DAH, coinciding with the start of exogenous feeding and the evidence of lipid storage in the liver. It was concluded that Malaysian mahseer larvae should certainly be able to ingest, and possibly digest and absorb, a formulated diet of $287 \mu \mathrm{m} \varnothing$ from 7 DAH onward.
\end{abstract}

Keyword: Mahseer; Ontegenic development; Tor tombroides; Mouth; Digestive tract 